\title{
Kırsal Kesimde Yaşayan Evli Kadınların Aile İşlevlerinin Evlilik Uyumuna Etkisi
}

\author{
Pinar TELLIOG $\breve{L} L U^{1} \& \mathrm{Hacl}$ ÖZDEMIR ${ }^{2}$
}

\section{$\ddot{O} z$}

Bu çalışmanın amacı, kırsal sekimde yaşayan evli kadınların ailelerinin çeşitli aile işlevlerini gösterme düzeylerinin evlilik uyumlarına etkisini incelemektir. Araştırmanın bir diğer amacı kırsal kesimdeyaşayan evli kadınların ailelerinin çeşitli aile işlevlerini gösterme düzeyleri ile evlilik uyumlarının; eğitim durumu, evlilik süresi, evlenme tipi ve çocuk sayısına göre anlamlı olarak farklılaşıp farklılaşmadığını saptamaktır. Araştırmanın modeli betimsel ilişkisel tarama modeli olup araştırmada seçkisiz olmayan örnekleme yöntemlerinden uygun örnekleme yöntemi kullanılmıştır. Araştırmanın evrenini, Samsun İlinin kırsal kesiminde yaşayan evli kadınlar oluşturmaktadır. Örneklemini Samsun İlinin İlkadım İlçesine bağlı Çatkaya, Uzgur, Çivril ve Kuşçulu köylerinde yaşayan evli 150 kadın oluşturmaktadır. Verilerin analizinde Pearson Korelasyon Katsayısı, One-WayAnova ve Çoklu Regresyon analizi kullanılmıştır. Araştırma sonucunda evlilik uyumu ile aile problem işlevi arasında pozitif yönlü ilişki olduğu sonucu elde edilmiştir. Ayrıca, ailelerin problem çözme işlevini yerine getirme işlevinin evlilik uyumu üzerinde anlamlı bir yordayıcılığa sahip olduğu sonucuna ulaşılmıştır. Araştırmanın bir diğer sonucuna göre; kırsal kesimde yaşayan evli kadınların ailelerinin genel işlevleri yerine getirme düzeyleri ile duygusal tepki verme, roller ve iletişim işlevlerini yerine getirme düzeyleri arasında pozitif yönde orta düzeyde; gereken ilgiyi gösterme, davranış kontrolü ve problem çözme işlevlerini yerine getirme düzeyleri ile de yine pozitif yönde düşük düzeyde anlamlı bir iliş̧i saptanmıştır.Araştırmanın son bulgularına göre kırsal kesimde yaşayan evli kadınların evlilik uyumları; eğitim durumu, evlilik süresi, evlenme tipi ve çocuk sayısı değişkenlerine göre anlamlı olarak farklılaşmamaktadır.

Anahtar Kelimeler: Evlilik, Evlilik Uyumu, Aile İşlevselliği

\section{The Effect of Family Functions of Married Women Living}

\section{in the Rural Area on Marriage Harmony}

\begin{abstract}
The purpose of this study was the family of married women living in rural areas do not show a variety of family functions is to examine the impact of compliance levels of marriage. Another purpose of the study is to examine the level of marital adjustment and the level of family functioning of married women living in rural areas; education status, duration of marriage, type of marriage and number of children. The model of there search was a descriptive relational screening model and appropriate sampling method was used for non-random sampling methods in the study. The universe of there search is composed of married women living in rural areas of Samsun province. The sample consists of 150 married women living in Çatkaya, Uzgur, Çivril and Kusçulu villages of Ilkadım district of Samsun. In the analysis of the data, Pearson Correlation Coefficient, One-Way Anova and Multiple Regression analysis were used. As a result of there search, it was concluded that there is a positive relation between marital adjustment and family problem function. It has also been found that the problem-solving function of the families has a significant predictor of marital adjustment. According to another result of there search; the levels of fulfillment of the general functions of married women living in rural areas, and the levels of emotional reaction, role and communication fulfillment are moderately positive; there is also a low level of positive correlation with the level of performing there quired demonstration, behavior control and problem solving functions. According to recent findings of the survey, marital adjustment of married women living in rural areas; education status, duration of marriage, type of marriage and number of children.
\end{abstract}

Keywords: Marriage, Marriage Adaptation, Family Functionality

\footnotetext{
${ }^{1}$ Ondokuz Mayıs Üniversitesi, pinartellioglu@gmail.com

${ }^{2}$ Ondokuz Mayıs Üniversitesi, Nefier55@gmail.com
}

Bu makale URKUND programı yardımıyla intihale karşı kontrol edilmiştir. 


\section{GİRİŞ}

Aile; biyolojik, sosyolojik ve psikolojik yap1s1 dolayısıyla birey ve toplumun ihtiyac1 olan cinsellik, üreme, korunma ve barınma, sevme ve sevilme, sevgiyi paylaşma, bağımlı ve bağımsız olma, ait olma, statü edinme, güven duyma, kendini gerçekleştirme, çocukların bakımı ve eğitimi, toplumsal töre ve ideallerin, kazanılan mal ve bilgilerin yeni nesillere aktarımı gibi pek çok görevi yerine getirmektedir. Aileler toplumdan topluma ve aynı toplum içerisinde farklılık gösterse de işlevleri; üreme yoluyla neslin devamlılığını, üyelerinin sosyal, psikolojik, ekonomik veeğitimsel doyumlarını sağlamak şeklinde evrenselleşmiştir (Özgüven, 2001:2).

Aile kavramı ve psikolojik düzeyde aile; 'aile yapıları', 'ailedeki etkileşim' ve 'ailedeki yaşam döngüsü' açılarından incelenebilir. Genel olarak bakıldığında, aile işlevlerinde aile içi iletişime, karşılıklı saygı ve işbirliğine büyük önem verilmektedir. Aile içi ilişkiler yapısı, ailenin işlevlerini sağlıklı bir biçimde yerine getirip getirememesinde önemli bir belirleyicidir. Sağlıklı işlevlere sahip aile; sorunlarını bir araya gelerek çözebilen, birbirlerine duygusal olarak bağlı ve özgürlüklerini kısıtlamayacak şekilde birbirleri ile ilgili, kendilerinden beklenilen rolleri etkili biçimde yerine getirebilen, davranışlarını aşırıya kaçmayacak şekilde kontrol edebilen, açık ve dolaysız bir iletişime sahip olan bireylerden oluşmaktadır (Bulut, 1990:4).
Her işlev, aile sisteminin bir parçasını oluşturmaktadır. Bu nedenle, sadece tek bir işlevin anlaşılması ailenin tümü hakkında bilgi veremez ve hiçbir işlev de sistemin bütününden ayrıştırılamaz. Yani ailede tüm işlevler birbirine bağlıdır. Örneğin; aile içi iletişim açık ve dolaysız değilse, diğer işlevlerin de beklenilen düzeyde yerine getirilmesi olanaksızdır. $\mathrm{O}$ halde, herhangi bir işlevde meydana gelebilecek bozulma, diğerlerini de etkileyecektir (Epstein ve Bishop, 1983; akt. Bulut, 1990:4).

İşlevlerini sağlıklı bir beraberlik içinde yerine getirmeyen aileler sağlıksı ailelerdir. $\mathrm{Bu}$ tür ailelerin önemli özelliği, iletişim işlevlerinin ve kişiler arası işlevlerinin bozuk olması ve kurallara aşırı bağlı olmalarıdır. Belirli roller, kişilerin üzerine zorla yüklenmiştir ve bunları değiştirmek zordur. Üyeleri birbirleriyle az konuşan ve açık bir iletişim içinde olmayan, aileyi ilgilendiren konulara birlikte çözüm aramayan, üyeleri birbirlerine gerçek bir yakınlık duymayan ve olumsuz duygular besleyen başka bir ifade ile özellikle ailede ebeveyn konumunda olan eşlerin aralarındaki uyumun düşük düzeyde olduğu aileler sağlıksızdır (Bulut, 1990:11). Çabukça ve Tutarel-Kışlak (2002), evli çiftlerde demografik değişkenlerle empati sahibi olmanın, evlilikte uyumu yordamada konusundaki etkileri üzerinde yaptığı çalışmada, empatinin evlilik uyumunun yordanmasında anlamlı değişken olduğu sonucuna varılmıştır. Demiray (2006) ise, elli bir çifte yer verdiği bir çalışmasında, ailenin yaptığı ziyaretler, evliliğin süresi ve çiftin hangi yaşta olduğunun, evlilikte uyumla ilişkisinin anlamlı olduğu sonucuna varılmıştır. Şener (2002), araştırmasında 
da genelde 35 yaş üzeri kişilerde erkek ve kadınların uyum puanları, eğitim düzeyleri, ailedeki ekonomik durum ve gelir yaş artışına bağlı olarak artmaktayken, kaç çocuğa sahip olunduğu ve çiftin yaş farkı azalma göstermektedir. Uyum puanlarına bakıldığında hem kadın hem de erkeğin çalıştı̆̆ ilişkilerde bu puan yüksek, emekli kadının bulunduğu ilişkilerde de puan düşük olmaktadır. Eşlerin iletişimi, kararları beraber alma ve beraber etkinliklerin bir parçası olma, hem eşinin hem de kendi akrabaları ile yeterli ilişkiye sahip olma ve iyi bir ekonomik duruma sahip olma konularındaki memnuniyet artınca, uyum puanlarının da arttığı görülmektedir.

Gürsoy'un (2004) çalışmasında, eşlerin evlilik öncesi birbirlerini ne kadar zamandır tanıdığı, çocuk sayısı, evliliğin ne zaman olduğu, eğitimleri, işleri, yaşları ve kaygı durumlarının, evlilik uyumunu ne derecede yordadığını gözlemlemiştir. Çalışmaya göre kadınlarda uyumu yordadığg düşünülen değişkenler eğitim ve kaygı; erkeklerdeyse iş durumu ve kaygının yordadığıgörülmüştür. Tuncay (2006), mükemmeliyetçi kişilerin evliliklerindeki uyumu kişilerarası düzeyde araştırmıştır. Evli çiftler üzerinde yapılan araştırmada, kadınlardaki mükemmeliyetçilikle alakalı aldıkları puanların yüksekliğiyle kaygı ve depresyonla alakalı ölçümlerde aldıkları yüksek puanların, uyum konusunda aldıkları düşük puanlarla arasında ilişki olduğu görülmüştür. Bir kadın eşinin kendisini eleştirdiğini düşünüyorsa bu durum, uyum puanında düşüklüğe neden olmaktadır. Erkeklerde ise depresyon ve mükemmeliyetçilik puanla- rında artış oldukça, uyum puanlarında düşüş olmuştur. Bir erkek, arada eleştirel bir yaklaşım olduğunu düşünüyorsa, bu durumda da kadınlarda olduğu gibi, evlilik uyumunda düşüş olmaktadır.

Evlilik kurumuna kentlerde yaşayan kadınlardan daha erken yaşta adım atan kırsal kesimde yaşayan kadınlar aile içerisinde yapmakla mükellef olduğu iş ve işlevleri yerine getirmede sorun yaşayabilmektedir. Bu durum eşleri ile arasındaki ilişkinin niteliğini de etkileyebilmektedir. Bu açıdan kırsal kesimde yaşayan kadınların evlilik uyumunu etkileyen unsurları ve aile işlevinin evlilik uyumundaki rolünü tespit etmek, kadınların uyumlu evlilik geçirmeleri noktasında fikir vermesi açısından önem arz etmektedir. Tüik (2018) raporuna göre; "evlenen çiftlerin saylsı 2016 yllında 594 bin 493 iken 2017 yllinda \%4,2 azalarak 569 bin 459 oldu. Kaba evlenme hizı binde 7,09 olarak gerçekleşti. Boşanan çiftlerin sayısı 2016 yılında 126 bin 164 iken 2017 yllında \%1,8 artarak 128 bin 411 oldu. Kaba boşanma hızı binde 1,6 olarak gerçekleştir." Boşanma ile ilgili sayısal veriler 2017 y1lında evlenen çiftlerin \%22'si kadar çift boşanmıştır. Bu durum boşanmanın ülkemizde bir problem alanı olduğunu göstermektedir. Boşanmanın sebeplerinden önemli bir bölümünün aile işlevselliği ve evlilik uyumu olduğu düşünülmektedir. Çalışmamızın çıktılarının aile işlevselliği ve evlilik uyumu noktalarında önemli bilgiler vereceği ve boşanma konusunda yapılacak çalışmalara temel teşkil edeceği düşünülmektedir. 
$\mathrm{Bu}$ bağlamda çalışmanın temel amacı kırsal sekimde yaşayan evli kadınların ailelerinin çeşitli aile işlevlerini gösterme düzeyleri ile evlilik uyumları arasındaki ilişkiyi incelemektir. Araştırmanın bir diğer amacı kırsal seminde yaşayan evli kadınların ailelerinin çeşitli aile işlevlerini gösterme düzeyleri ile evlilik uyumlarının; eğitim durumu, evlilik süresi, evlenme tipi ve çocuk sayısına göre anlamlı olarak farklılaşıp farklılaşmadığını saptamaktır. Araştırmanın temel amacı kapsamında aşağıdaki alt problemlere cevaplar aranacaktır;

1. Kırsal kesimde yaşayan evli kadınların ailelerinin problem çözme, genel işlevler, iletişim, roller, duygusal tepki verme, gereken ilgiyi gösterme, davranış kontrolü işlevlerini yerine düzeyleri evlilik uyumlarını yordamakta mıdır?

2. Kırsal kesimde yaşayan evli kadınların evlilik uyumları eğitim durumuna, evlilik süresine, evlenme tipine ve çocuk sayısına göre anlamlı olarak farklılaşmakta mıdır?

\section{YÖNTEM}

\subsection{Evren ve Örneklem}

$\mathrm{Bu}$ araştırmada betimsel ilişkisel tarama modeli kullanılmıştır. Araştırmanın evrenini, Samsun İlinin kırsal kesiminde yaşayan evli kadınlar, örneklemini ise Samsun İlinin İlkadım İlçesine bağlı Çatkaya, Uzgur, Çivril ve Kuşçulu köylerinde yaşayan 150 evli kadın oluşturmaktadır. Araştırmada seçkisiz olmayan örnekleme yöntemlerinden uygun örnekleme yöntemi kullanılmıştır. Bunun için de araştırma yapıldığı sıradan ulaşılabilen, kırsal kesimde yaşayan evli kadınlar araştırmanın örneklemini oluşturmuştur. Araştırmanın örneklemin oluşturan kırsal kesimde yaşayan evli kadınlara ait sosyo-demografik bilgiler aşağıda verilmiştir.

Örneklemin yaş aralıklarına göre dağılımına baktığımızda \%2,7'si 18-24 yaş (4), \%19,3'ü 25-30 yaş (29), \%46,7'si 31-45 yaş (70), \%25,3'ü 45-59 yaş (38), \%6'sı 60 ve üstü yaş (9) aralığındadır. Örneklemin eğitim durumuna göre dağılımına baktığımızda \%12,7'si sadece okur yazar (19) durumundadir ve \%38,7'si ilköğretim (58), \%34'ü lise (51), $\% 14,7$ 'si üniversite (22) mezunudur. Örneklemin evlilik süresine göre dağılımına baktığ1mızda \%9,3'ü 1-5 y1l (14), \%20,7'i 6-10 y1l (31), \%14,7'si 11-15 (22), \%16,7'si 16-20 (25), \%38,7’si 21 ve üstü (58) yıldır evlidir. Örneklemin evlenme tipine göre dağılımına baktığ1mızda (67), \%48'i anlaşarak (72), \%2'si zorla (3), \%5,3'ü kaçarak (8) evlenmiştir. Örneklemin sahip olduğu çocuk sayısına göre dağıl1mına baktığımızda . \%18'i bir çocuğa (27), \%38'i iki çocuğa (57), \%26,7'si üç çocuğa (40), \%13,3'ü dört ve üstü çocuğa (20) sahiptir.

\subsection{Veri Toplama Araçları}

Araştırmada veri toplama aracı olarak, Evlilik Uyum Ölçeği, Aile Değerlendirme Ölçeği ve sosyo-demografik bilgilere ulaşabilmek için Kişisel Bilgi Formu kullanılmıştır.

\subsubsection{Evlilik Uyum Ölçeği (EUÖ)}

Locke ve Wallace (1959) tarafindan geliştirilen ve Kışlak (1996) tarafından Türkçeye uyarlanıp geçerlik ve güvenirlik çalışması yapılan Evlilik Uyum Ölçeği (EUÖ), evlilik ilişkisinden alınan evlilik uyumunu ölçmeyi amaçla- 
maktadır. Ölçek, seçenek sayıları farkl1 15 maddeden oluşmaktadır. Ölçekten alınan toplam puan 0-60 arasında değişmektedir. 43 puanın üzerinde alanlar evlilik ilişkileri açısından uyumlu, altında alanlar ise uyumsuz olarak kabul edilmektedir. Kışlak (1996) ölçeğin güvenirliği için yaptığı çalışmada cronbach alfa iç tutarlı1ık katsayısı. 80, iki yarı güvenirlik katsay1s1 da. 67 olarak bulunmuştur (Kışlak, 1996: 36).

\subsubsection{Aile Değerlendirme Ölçeği (ADÖ)}

Aile Değerlendirme ölçeği, Amerika Birleşik Devletleri'nde Brown Üniversitesi ve Buttler Hastanesi tarafindan Aile Araştırma Programı çerçevesinde geliştirilmiştir ve ailenin işlevlerini hangi konularda yerine getirip getirmediğini ortaya çıkarmak amacıyla kullanılmaktadır. Ölçek; problem çözme, iletişim, roller, duygusal tepki verme, gereken ilgiyi gösterme, davranış kontrolü, genel fonksiyonlar olmak üzere yedi alt boyuttan ve toplam 60 maddeden oluşmaktadır.

Ölçeğin Türkiye'deki geçerlik ve güvenirlik çalışması Bulut (1989) tarafindan iç tutarl11ık yöntemleriyle sınanmıştır. İç tutarlı1ı̆ğ 67 deneğin verdikleri cevaplar üzerinden her bir boyut için Cronbach alfa katsayıları hesaplanarak yapılmıştır. Problem Çözme için 0.80 , İletişim için 0.71, Roller için 0.42, Duygusal Tepki Verebilme için 0.59, Gereken İlgiyi Gösterme için 0.38, Davranış Kontrolü için 0.52, Genel Fonksiyonlar için 0.86 olarak bulunmuştur ( $p=$ $0.001)$.

\subsubsection{Kişisel Bilgi Formu}

$\mathrm{Bu}$ araştırma için hazırlanan kişisel bilgi formu, araştırmanın örneklemi oluşturan kırsal kesimde yaşan evli kadınların yaş aralıkları, eğitim düzeyleri, evlilik süreleri, evlenme tipleri ve çocuk sayıları hakkında sorulan sorulardan oluşmaktadır.

\subsection{Verilerin Toplanması ve Analizi}

Araştırma kapsamında yapılan istatistiksel analizlerde, araştırma problemi ve değişkenlerin özellikleri göz önünde bulundurularak Pearson Korelasyon Katsayısı, One-WayAnova ve Çoklu Regresyon analizleri kullanılmıştır One-WayAnova ve Pearson Korelasyon Katsayısı analiz yöntemlerinin normallik şartını sağlayabilmek amacıyla normallik varsayımı örneklem büyüklüğü dikkate alınarak ölçme ve değerlendirme uzmanlarının önerileri doğrultusunda çarpıklık ve basıklık değerleri hesaplanmış, histogram grafikleri incelenmiştir. Çarpıklık ve basıklık değerlerinin tüm değişkenler için $-1,5$ ile $+1,5$ değerleri arasında olup dağılımların normallikten manidar düzeyde sapmadığı görülmüştür. Bu sebeple araştırma verileri normal dağ 1 lım gösterdiği için parametrik testler kullanılmıştır.

\section{BULGULAR}

$\mathrm{Bu}$ bölümde, araştırmaya katılan kırsal kesimde yaşan evli kadınların ölçeklere verdikleri cevaplar doğrultusunda elde edilen verilerin istatistiksel çözümlemeleri sonucunda ulaşılan bulgular yer almaktadır. 
Kırsal kesimde yaşayan evli kadınların ailelerinin problem çözme, genel işlevler, iletişim, roller, duygusal tepki verme, gereken ilgiyi gösterme, davranış kontrolü işlevlerini yerine düzeylerinin evlilik uyumlarını yordamasına ilişkin bulgular
Kırsal kesimde yaşayan evli kadınların evlilik uyum, ailelerinin problem çözme, genel işlevler, iletişim, roller, duygusal tepki verme, gereken ilgiyi gösterme, davranış kontrolü işlevlerini yerine düzeyleri arasındaki ilişkinin anlamlılık düzeyini test etmek amacıyla Pearson Momentler Çarpımı Korelasyon katsayısı hesaplanmıştır. İlgili değişkenlere ilişkin bulgular aşağıdaki tabloda yer verilmiştir.

Tablo 1. Değişskenler Arasındaki Korelasyon Katsayıları ve Betimsel İstatistikler

\begin{tabular}{|c|c|c|c|c|c|c|c|c|}
\hline & 1 & 2 & 3 & 4 & 5 & 6 & 7 & 8 \\
\hline 1.Evlilik Uyumu & - & & & & & & & \\
\hline 2.Genel İşlev & .040 & - & & & & & & \\
\hline 3.Gereken İlgiyi G. & .064 & $.283 * *$ & - & & & & & \\
\hline 4.Davranış Kontrolü & .066 & $.275 * *$ & $.485 * *$ & - & & & & \\
\hline 5.Duygusal Tepki Verme & .123 & $.346 * *$ & $.461 * *$ & $.352 * *$ & - & & & \\
\hline 6.Roller & .112 & $.440 * *$ & $.505 * *$ & $.432 * *$ & $.475^{* *}$ & - & & \\
\hline 7.İletişim & .047 & $.388 * *$ & $.239 * *$ & .136 & $.269 * *$ & $.459 * *$ & - & \\
\hline 8.Problem Çözme & $.406 * *$ & $.178^{*}$ & $.203^{*}$ & $.177^{*}$ & .100 & .058 & $.264 * *$ & - \\
\hline$\overline{\mathrm{X}}$ & 36.40 & 30.01 & 16.68 & 24.52 & 15.86 & 29.11 & 21.04 & 10.89 \\
\hline SS & 6.24 & 3.44 & 3.38 & 3.62 & 2.83 & 3.71 & 3.36 & 3.46 \\
\hline
\end{tabular}

Not. $\mathrm{p}<.05^{*}, \mathrm{p}<.001^{* *}$.

Tablo 1'de görüldüğü gibi kırsal kesimde yaşayan evli kadınların evlilik uyumları ile ailelerinin problem çözme $(r=.406, p<.001)$ işlevini yerine getirme düzeyi arasında pozitif yönde orta düzeyde anlamlı bir ilişki saptanmıştir.
Kırsal kesimde yaşayan evli kadınların ailelerinin genel işlevleri yerine getirme düzeyleri ile duygusal tepki verme $(\mathrm{r}=.346, \mathrm{p}<001)$, roller $(\mathrm{r}=.440, \mathrm{p}<.001)$ ve iletişim $(\mathrm{r}=.388$, $\mathrm{p}<.001)$ işlevlerini yerine getirme düzeyleri arasında pozitif yönde orta düzeyde; gereken ilgiyi 
gösterme $(\mathrm{r}=.283, \mathrm{p}<001)$, davranış kontrolü $(\mathrm{r}=.275, \mathrm{p}<.001)$ ve problem çözme $(\mathrm{r}=.175$, $\mathrm{p}<.05)$ işlevlerini yerine getirme düzeyleri ile de yine pozitif yönde düşük düzeyde anlamlı bir ilişki saptanmıştır.

Kırsal kesimde yaşayan evli kadınların ailelerinin gereken ilgiyi gösterme işlevini yerine getirme düzeleri ile davranış kontrolü $(\mathrm{r}=.485, \mathrm{p}<.001)$, duygusal tepki verme $(\mathrm{r}=.461$, $\mathrm{p}<.001)$ ve roller $(\mathrm{r}=.505, \mathrm{p}<.001)$ işlevlerini yerine getirme düzeyleri arasında pozitif yönde orta düzeyde; iletişim $(\mathrm{r}=.239, \mathrm{p}<.001)$ ve problem çözme $(r=.203, p<.05)$ işlevlerini yerine getirme düzeyleri ile de yine pozitif yönde düşük düzeyde anlamlı bir ilişki saptanmıştır.

Kırsal kesimde yaşan evli kadınların ailelerinin davranış kontrolü işlevini yerine getirme düzeyleri ile duygusal tepki verme $(\mathrm{r}=.352, \mathrm{p}<.001)$ ve roller $(\mathrm{r}=.432, \mathrm{p}<.001)$ işlevlerini yerine getirme düzeyleri arasında pozitif yönde orta düzeyde, problem çözme $(r=-$ $.177, \mathrm{p}<.05)$ işlevini yerine getirme düzeyi ile de negatif yönde düşük düzeyde anlamlı bir ilişki saptanmıştır.

Kırsal kesimde yaşan evli kadınların ailelerinin duygusal tepki verme işlevini yerine getirme düzeyleri ile roller $(r=.475, \mathrm{p}<.001)$ iş- levlerini yerine getirme düzeyleri arasında pozitif yönde orta düzeyde; iletişim $(r=.269, \mathrm{p}<.001)$ işlevini yerine getirme düzeyleri ile de yine pozitif yönde düşük düzeyde anlamlı bir ilişki saptanmıştır.

Kırsal kesimde yaşan evli kadınların ailelerinin roller işlevini yerine getirme düzeyleri ile iletişim $(\mathrm{r}=.459, \mathrm{p}<.001)$ işlevlerini yerine getirme düzeyleri arasında pozitif yönde orta düzeyde; iletişim işlevini yerine getirme düzeyleri ile problem çözme $(r=.264, p<.001)$ işlevlerini yerine getirme düzeyleri arasında da yine pozitif yönde düşük düzeyde anlamlı bir ilişki saptanmıştır.

Kırsal kesimde yaşayan evli kadınların ailelerinin problem çözme, genel işlevler, iletişim, roller, duygusal tepki verme, gereken ilgiyi gösterme, davranış kontrolü işlevlerini yerine getirme düzeyi değişkenlerine göre evlilik uyumlarının yordanmasına ilişkin Çoklu Regresyon Analizi yapılmıştır. Değişkenler arasındaki ikili korelasyonların .80'nin altında olduğu, çoklu bağlantı problemi olmadığı ve veriler normal dağılım gösterdiği için ilgili değişkenler regresyon analizine katılmıştır. Çoklu Regresyon Analizi sonuçları Tablo 2'de verilmiştir. 
Tablo 2. Evlilik Uyumunun Yordanmasına İlişkin Çoklu Regresyon Analizi Sonuçları

\begin{tabular}{|c|c|c|c|c|c|c|c|}
\hline & B & $\begin{array}{l}\text { Stan- } \\
\text { dart } \\
\text { Hata }\end{array}$ & $\beta$ & $\mathbf{T}$ & $\mathbf{p}$ & $\begin{array}{l}\text { İkili } \\
\text { r }\end{array}$ & $\begin{array}{l}\text { Kismi } \\
\mathbf{R}\end{array}$ \\
\hline Sabit & 34.666 & 5.091 & - & 6.810 & .000 & - & - \\
\hline Problem Çözme & .866 & .150 & .481 & 5.772 & .000 & .406 & .436 \\
\hline İletişim & -.274 & .169 & -.147 & -1.618 & .108 & -.047 & -.135 \\
\hline Roller & -.045 & .173 & -.027 & -.260 & .795 & -.112 & -.022 \\
\hline Duygusal Tepki V. & -.137 & .200 & -.062 & -.685 & .494 & -.123 & -.057 \\
\hline Gereken İlgili G. & .213 & .178 & .115 & 1.197 & .233 & -.064 & .100 \\
\hline Davranış Kontrolü & .065 & .155 & .038 & .419 & .676 & -.066 & .035 \\
\hline Genel İşlevler & -.141 & .161 & -.078 & -.874 & .383 & -.040 & -.073 \\
\hline
\end{tabular}

Tablo 2'de görüldügü gibi problem çözme, iletişim, roller, duygusal tepki verme, gereken ilgiyi gösterme, davranış kontrolü ve genel işlevler değişkenleri birlikte, kırsal kesimde yaşayan evli kadınların evlilik uyumları ile orta düzeyde anlamlı bir ilişki vermektedir $\left(\mathrm{R}=.454, \mathrm{R}^{2}=.206\right)$. Ad1 geçen yedi değişken birlikte, evlilik uyumundaki varyansın yaklaşık \%21'ini açıklamaktadır.

Standardize edilmiş regresyon katsay1sına ( $\beta$ ) göre, yordayıcı değişkenlerin evlilik uyumu üzerindeki önem sırası; problem çözme, iletişim, gereken ilgiyi gösterme, genel işlevler, duygusal tepki verme, davranış kontrolü ve rollerdir. Regresyon katsayılarının anlamlılı̆̆ına ilişkin t-testi sonuçları incelendiğinde ise, sadece problem çözme değişkeninin evlilik uyumu üzerinde anlamlı bir yordayıcılığı olduğu görülmektedir. İletişim, roller, duygusal tepki verme, gereken ilgiyi gösterme, davranış kontrolü, genel işlevler önemli bir etkiye sahip değildir.

- Kursal kesimde yaşayan evli kadınların evlilik uyumları eğitim durumuna, evlilik süresine, evlenme tipine ve çocuk sayısına göre anlamlı olarak farklılaşıp farklılaşmadığına ilişkin bulgular

Kırsal kesimde yaşayan evli kadınların evlilik uyumlarının eğitim durumu, evlilik süresi, evlenme tipi ve çocuk sayısı değişkenleri 
bakımında anlamlı olarak farklılaşıp farklılaşmadığını test etmek amacıyla yapılan Tek
Yönlü Varyans Analizi (One-WayAnova) sonuçları Tablo 3'te verilmiş̧ir.

Tablo 3. Evlilik Uyum Puanlarına Yönelik Betimsel İstatistikler ve Değişkenlere İlişkin OneWayAnova Sonuçları

\begin{tabular}{|c|c|c|c|c|c|c|c|c|c|c|}
\hline Grup & $\mathbf{N}$ & $\overline{\mathrm{X}}$ & SS & $\begin{array}{l}\text { Varyans } \\
\text { Kaynağı }\end{array}$ & $\begin{array}{l}\text { Kareler } \\
\text { Toplamı }\end{array}$ & sd & $\begin{array}{c}\text { Kareler } \\
\text { Ortalaması }\end{array}$ & & $\mathbf{p}$ & $\begin{array}{c}\text { Anlamlı } \\
\text { Fark }\end{array}$ \\
\hline Okuryazar & 19 & 36.36 & 7.00 & G.Arası & 88.338 & 3 & 29.4460 & .751 & .524 & $\begin{array}{c}\text { Fark } \\
\text { Yoktur }\end{array}$ \\
\hline İlköğretim & 58 & 35.51 & 6.31 & G.İçi & 5725.856 & 146 & 39.218 & & & \\
\hline Lise & 51 & 37.29 & 6.28 & Toplam & 5814.193 & 149 & & & & \\
\hline Üniversite & 22 & 36.72 & 6.32 & & & & & & & \\
\hline Toplam & 150 & 36.40 & 6.24 & & & & & & & \\
\hline
\end{tabular}

Betimsel İstatistikler $\quad$ Evlilik Süresine göre ANOVA Sonuçları

\begin{tabular}{|c|c|c|c|c|c|c|c|c|c|c|}
\hline Grup & $\mathbf{N}$ & $\overline{\mathrm{X}}$ & SS & $\begin{array}{l}\text { Varyans } \\
\text { Kaynağı }\end{array}$ & $\begin{array}{l}\text { Kareler } \\
\text { Toplamı }\end{array}$ & sd & $\begin{array}{l}\text { Kareler } \\
\text { Ortalaması }\end{array}$ & $\mathbf{F}$ & $\mathbf{p}$ & $\begin{array}{c}\text { Anlamlı } \\
\text { Fark }\end{array}$ \\
\hline $1-5$ yıl & 14 & 34.50 & 6.75 & G.Aras1 & 88.739 & 3 & 22.185 & .562 & .691 & $\begin{array}{c}\text { Fark } \\
\text { Yoktur }\end{array}$ \\
\hline 6-10 yil & 31 & 35.80 & 6.57 & G.İçi & 5725.454 & 145 & 39.486 & & & \\
\hline $11-15$ yll & 22 & 36.54 & 6.97 & Toplam & 5814.193 & 149 & & & & \\
\hline $16-20$ & 25 & 37.28 & 6.18 & & & & & & & \\
\hline 21 ve üstü & 58 & 36.75 & 5.76 & & & & & & & \\
\hline Toplam & 150 & 36.40 & 6.24 & & & & & & & \\
\hline
\end{tabular}


Betimsel İstatistikler
Evlenme Tipine göre ANOVA Sonuçları

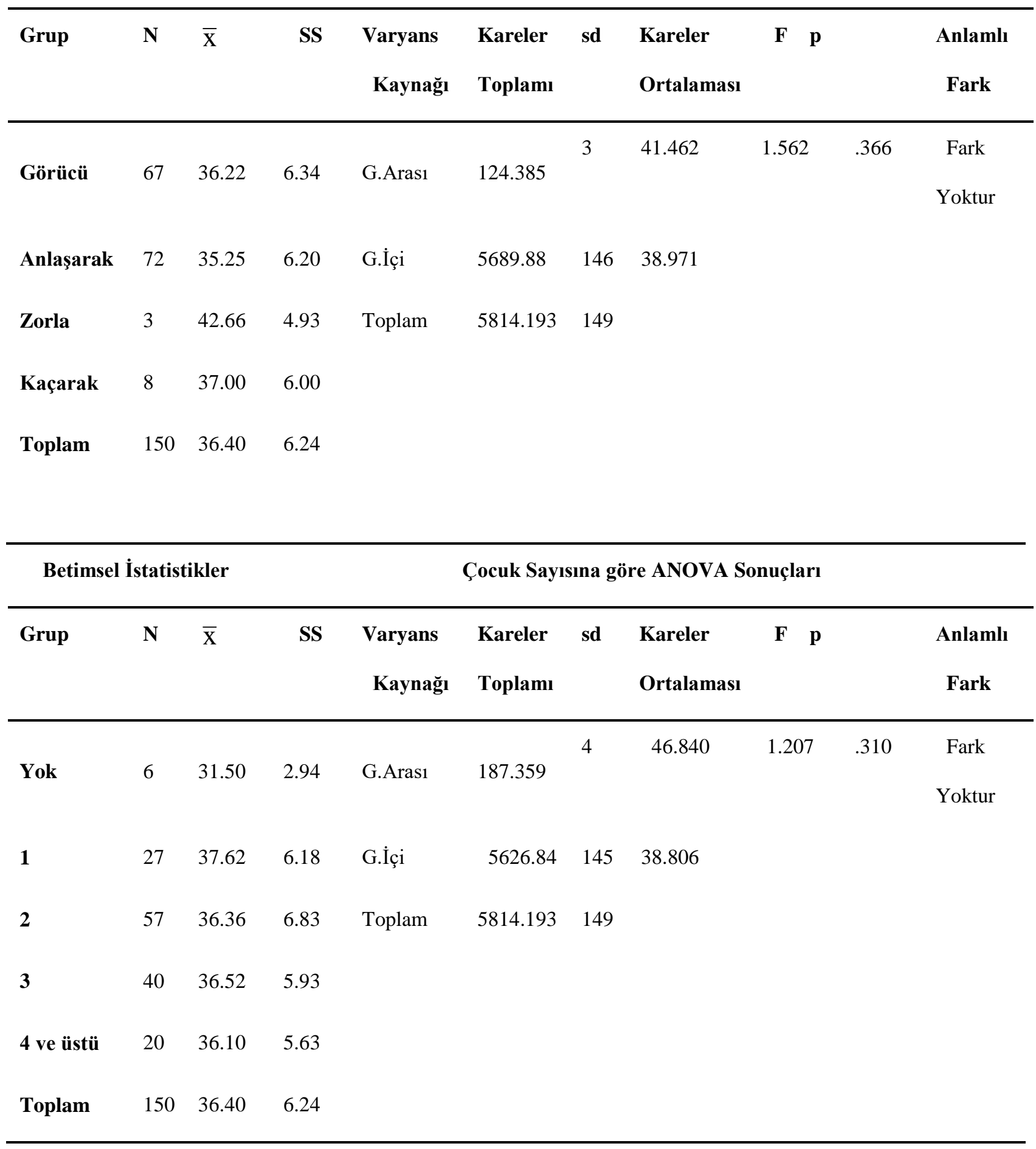

Tablo 3'te görüldüğü gibi kırsal kesimde yaşa$\mathrm{f}(3.146)=.751, \mathrm{p}>.05 ; \mathrm{f}(3.145)=.562, \mathrm{p}>.05 ;$ yan evli kadınların evlilik uyumları, eğitim du$f(3.146)=1.562, p>.05 ; f(4.145)=1.207, p>.05$ yısı değişkenlerine göre anlamlı olarak farkl1laşmamaktadır. 


\section{TARTIŞMA ve SONUÇ}

Araştırmanın ilk ulaşılan sonucuna göre kırsal kesimde yaşayan evli kadınların evlilik uyumları ile ailelerinin problem çözme işlevini yerine getirme düzeyi arasında pozitif yönde orta düzeyde anlamlı bir ilişki saptanmıştır. Ayrıca ailelerin problem çözme işlevini yerine getirme işlevinin evlilik uyumu üzerinde anlamlı bir yordayıcılığa sahip olduğu sonucuna ulaşılmıştır. Yani ailelerin problem çözme becerileri arttıkça evlilik uyumları da artmaktadır ve problem çözme evlilik uyumu üzerinde önemli bir etkiye sahiptir. Konuyla ilgili saptanan sonuç literatürle de paralellik göstermektedir. Ailenin problem çözme işlevini yerine getirebilmesi için çatışma çözme becerileri noktasında yeterliliğinin olması bilinen bir gerçektir. Yapılan araştırmalarda olumsuz çatışma çözme stili ile evlilik uyumu arasında negatif yönde anlamlı bir ilişki olduğu, çatışma çözme stillerinin evlilik uyumunu önemli ölçüde yordadığı saptanmıştır (Özen, 2006: 98). Yirmi yıldan fazla süredir evli olan yirmi sekiz çift üzerine yapılan araştırmaya göre problem çözme ve güçlü iletişim becerileri, evlilik doyumunun yordayıcılaridır (Norgren, Souza, Kaslowlll, Hammerschmidt \& Sharlin, 2004). Tüm bunlar dikkate alındığında evliliklerde uyumu artırabilmek için ailelerin problem çözme becerilerini edinmesi ve bu becerileri aile içinde işlevsel olarak kullanmas1 son derece önemlidir.

Araştırmanın bir diğer sonucuna göre; kırsal kesimde yaşayan evli kadınların ailelerinin genel işlevleri yerine getirme düzeyleri ile duygusal tepki verme, roller ve iletişim işlevlerini yerine getirme düzeyleri arasında pozitif yönde orta düzeyde; gereken ilgiyi gösterme, davranış kontrolü ve problem çözme işlevlerini yerine getirme düzeyleri ile de yine pozitif yönde düşük düzeyde anlamlı bir ilişki saptanmıştır. Yani ailelerin genel işlevleri yerine getirme düzeyleri arttıkça duygusal tepki verme, roller, iletişim, gereken ilgiyi gösterme, davranış kontrolü, problem çözme işlevlerini yerine getirme düzeyleri artmaktadır. Bu durum ailenin işlevsel olmasının aile içi iletişimi, aile arasında iş paylaşımını ve yardımlaşmayı, birbirlerinin duygularını anlama noktasında çaba içerisinde olmayı, davranışlarını kontrol ederek problem çözme eğilimi göstermeyi olumlu yönde etkileyeceğini düşündürtmektedir. Tüm bunların da evlilik uyumuna olumlu katkılar sağlayacağı açıktır. Bir diğer sonuca göre,kırsal kesimde yaşayan evli kadınların ailelerinin gereken ilgiyi gösterme işlevini yerine getirme düzeyleri ile davranış kontrolü, duygusal tepki verme ve roller işlevlerini yerine getirme düzeyleri arasında pozitif yönde orta düzeyde; iletişim ve problem çözme işlevlerini yerine getirme düzeyleri ile de yine pozitif yönde düşük düzeyde anlamlı bir ilişki saptanmıştır. Aile bireylerinin birbirlerine karşı ilgili ve duyarlı olmaları, birbirlerinin duygularına tepki vermelerini sağladı ̆̆ı ve empati yeteneklerini geliştirdiği ve buradan hareketle evlilik uyumunu artırdığı düşünülebilir. Ayup ve Iqbal (2012) iletişim becerilerinin evlilik doyumuyla ilişkili olduğunu ortaya koymuşlardır. Norgren, Souza, Kaslowlll, Hammerschmidt ve Sharlin (2004) evlilik doyumunun iletişim becerilerini yordadığını belirtirmiştir. 
Yukarıda ifade edilenler dikkate alınd1ğında aile işlevlerine ilişkin değişkenler ailenin aile içi ilişkilerinin dinamik yapısını etkiler ve doğrudan veya dolaylı olarak evlilik uyumuna pozitif veya negatif etki yapmaktadır. Tufan'a (1983) göre ailenin fonksiyonel ve fonksiyonel olmaması yani sağlıklı ve sağlıksız olması, sosyo-ekonomik özellikleri, toplumdaki hizmet ve olanaklar, aile üyelerinin genetik özellikleri, kişilikleri ve aile içi ilişkilerin dinamik yapısı ile ilgilidir. Sorunlarını bir araya gelerek çözebilen, birbirlerine duygusal olarak bağlı ve özgürlüklerini önlemeyecek şekilde ilgili, herkesin kendinden beklediği rolü etkin biçimde yerine getirebildiği, birbirlerinin davranışlarını aşırıya kaçmayacak şekilde kontrol edebilen ve aralarında açık, rahat, dolaysız bir iletişim bulunan aileler, işlevlerini yerine getiren sağlıklı ailelerdir (Bulut, 1990: 67).

Araştırmanın son bulgularına göre kırsal kesimde yaşayan evli kadınların evlilik uyumları, eğitim durumu, evlilik süresi, evlenme tipi ve çocuk sayısı değişkenlerine göre anlamlı olarak farklılaşmamaktadır. Literatür incelendiğinde araştırmanın bu bulgularını destekleyen veya desteklenmeyen araştırma sonuçlarına ulaşılmıştır. Kadınların toplumsal bask1 altında olmaları, bireysel doyumlarını olumsuz yönde etkilemektedir, ancak eğitim düzeyi yüksek kadınların bu baskıyı daha az hissetmektedir ve bireysel doyumları artmaktadır . Bireysel doyumun artmasının evlilik uyumunu da olumlu yönde etkileyeceği düşünülebilir. Eğitim düzeyi yükseldikçe eşlerin çatışma ve anlaşmazlıklarını karşılıklı saygı çerçevesinde çöz- meye çalışırlar, eğitim seviyesi düştükçe de empati düzeyi azalabilir ve bu da eşlerin uyumunu olumsuz yönde etkileyebilir. Eğitim düzeyi arttıkça evlilik ilişkilerini ve evlilikle ilgili duyguları olumlu yönde etkilediği, eğitim düzeyi düştükçe de bu parametrelerin azaldığ 1 görülebilir (Demiray, 2006: 51).

Araştırmanın bir başka sonucuna göre evlilik uyumu ile evlenme tipine göre anlamlı olarak farklılaşmamaktadır. Araştırmanın bu bulgusunun aksine literatürde evlenme tipi ile evlilik uyumu arasında anlamlı ilişkiler saptanmıştır. Kadınların kişilik özellikleri, evlilik doyumunu en iyi yordayan değişkenken, flört ederek evlenen kadınların genel ruh hali, evlilik doyumunu en iyi yordamaktadır. Eşlerin ilişkiye yaptıkları yatırım arttıkça ilişki doyumu artmakta, evlilik doyumu arttıkça da ilişkiye yapılan yatırımın artmakta olduğu görülmektedir. Görücü usulü evlilik yapan ev kadınların, muhtemelen evliliklerinde aradığını bulamadığından dolayı anksiyete, somatizasyon belirtilerinin tanışarak evlenenlerden daha çok görüldügünü ifade etmişlerdir. Yapılan bir çalışmada görücü usulü ile evleneler daha çok çatışma yaşamakta ve bunun da evlilik uyumunu azaltıcı bir etken olduğunu tespit edilmiştir. Bir birini yeterince iyi tanıyarak evlenen bireylerde evliliğe dair beklentilerinde bir değişiklik olmamakla beraber, yeterince birbirini tanımadan yapılan evliliklerde az da olsa evliliğe dair beklentileri değişmektedir. Evliliğe hazır oluş da evlilik uyumunu doğrudan etkilemektedir (Güngör, 2007: 36). 
Bir diğer sonuca göre evlilik süresine göre kırsal kesimde yaşan evli kadınların evlilik uyumları evlilik süresine göre anlamlı farklılık göstermemektedir. Fışıloğlu (1992) yüksek lisans öğrencilerinin evlilik süreleri ile evlilik uyumları arasındaki ilişkiyi incelemiş, bu iki değişken arasında anlamlı bir ilişki olmadığını belirlemiştir.Evlilik süresinin, cinsiyetler açısından evlilik uyumunu nasıl etkilediğine ilişkin araştırmalarda ise, kadınlarda evlilik uyumunun evlilik süresi arttıkça düştüğü, erkeklerde ise yükseldiği belirlenmiştir. Turan (1997) tarafından yapılan bir çalışmada ise erkekler için evlilik süresi anlamlı bulunurken, kadınlar için anlamlı bir ilişki bulunamamıştır.

Bir diğer sonuca göre evlilik süresine göre kırsal kesimde yaşan evli kadınların evlilik uyumları çocuk sayısına göre anlamlı farklılık göstermemektedir. Evlilik uyumunun çocuk sayısına bağlı olarak değişmediğine işaret eden çalışmalar bulunmaktadır. Çocuklar küçük yaştayken evlilikte istikrarı artırmaktadır, diğer yandan da evlilikte kaliteyi düşürmek gibi çelişkili bir etkiye sahiptir. Ayrıca evlilik kalitesindeki düşüşler ve artışlar, depresyon belirtileri, çocuğun cinsiyeti ve hamileliğin planlanmış olup olmadığıyla öngörülebildiği belirtilmektedirler. Evlilikteki problemlerin çiftlerin çocuklarını etkilediği, çocuklarda depresyon, yetersiz sosyal beceriler, kötü sağlık sonuçları, düşük akademik başarı ve davranış problemleri oluşturduğu bildirilmektedir. Dolayısıyla eşler arasındaki uyum ile çocuğun uyumu arasındaki ilişki sıklıkla araştııılan konuların başında gelmektedir.
Tüm bu sonuçlar dikkate alındığında ailelerin aile içinde meydana gelen problemler karşısında problem çözme becerilerini devreye sokmaları onların evlilik uyumlarını artırdığ söylenebilir. Ayrıca sağlıklı bir ailede olması gereken ailenin genel olarak ailesel işlevleri paylaşarak yapabilmesinin ardında aile bireylerinin birbirlerine karşı şeffaf bir biçimde duygularını açabilmelerinin, ev içi rolleri paylaşabilmelerinin, empatiyle engelsiz bir iletişim kurabilmelerinin, birbirlerine karşı gereken zamanı ve ilgili sunabilmelerinin, birbirlerine karşı davranışlarında otokontrollerini sağlayarak problemlerin çözümüne ilişkin gayret gösterebilmelerinin olduğu düşünülebilir.

\section{5.ÖNERILER}

$\mathrm{Bu}$ çalışmanın sonucunda elde edilen bulgulara dayalı olarak aşağıdaki önerilere yer verilmiştir:

1. Bireylerin evlilik uyum düzeylerini arttırmalarında orta düzeyde etkili olan aile işlevlerine önem vermeleri, bu sayede daha uyumlu bir evlilik yaşayabilecekleri önerilmektedir.

2. Konu ile ilgili araştırma yapacak olan araştırmacılar, kırsal kesimden ve Samsun ilinden daha geniş kitlelere ulaşarak çalışmalarını yürütebilirler.

3. Evlilik uyumu ve aile işlevi ile ilgili daha farklı ölçeklerden yararlanarak farklı boyutlarda araştırma yapabilirler. 


\section{Kaynakça}

Ayub, M., Iqbal, S. (2012). The factors predicting marital satisfaction: a gender difference in pakistan. The International Journal of Interdisciplinary Social Science,6(7), 63-73

Bulut, I. (1990). Aile Değerlendirme Ölçeği El Kitabı. Ankara: Özgüzeliş Matbaası.

Demiray, Ö. (2006). Evlilikte Uyumun Demografik Özelliklere Göre İncelenmesi, Diyarbakır: Dicle Üniversitesi Sosyal Bilimler Enstitüsü, Yayımlanmamış Yüksek Lisans Tezi.

Fışıloğlu, H. (1992). Lisans Üstü Öğrencilerin Evlilik Uyumu, Psikoloji Dergisi, (7), 16-23.

Güngör, H. C. (2007). Evlilik Doyumunu Açıklamaya Yönelik Bir Model Geliştirme, Ankara: Gazi Üniversitesi, Yayımlanmamış Yüksek Lisans Tezi.

Gürsoy, Ç. (2004). Kayg1 ve Demografik Değişkenlerin Evlilik Uyumu İle İlişkisi, Mersin: Mersin Üniversitesi Sosyal Bilimler Enstitüsü, Yayınlanmamış Yüksek Lisans Tezi.

Norgren, M.B.P., Souza, R.M., Kaslowlll, F., Hammerschmidt, V., Sharlin, V.S.A. (2004). Possível. [marital satisfaction in long-lasting marriages: a feasible construction.] Estudos de Psicologia (Natal), 9 (3), 575-584.
Özen, Aç (2006). Evlilik Uyumunun Yordayıcıları Olarak Karl ve Kocaların Değer Uyumları ve Eşlerin Çatışma Çözüm Stilleri, Ankara: ODTÜ Sosyal Bilimler Enstitüsü, Yayımlanmamış Yüksek Lisans Tezi.

Özgüven, İ. (2001). Ailede İletişim Ve Yaşam. Ankara: PDREM Yayınları.

Şener, A. (2002). Ailede Eşler Arası Uyuma Etki Eden Faktörlerin Araştırılması, Ankara: Hacettepe Üniversitesi Sağlık Bilimleri Enstitüsü, Yayınlanmamış Doktora Tezi.

Tuncay, E. (2006). Mükemmeliyetçiliğin Evlilik Uyumu Üzerindeki Yordayıcı Rolü, Ankara: ODTÜ Sosyal Bilimler Enstitüsü, Yayınlanmamış Yüksek Lisans Tezi.

Turan, M. (1997). Erzurum'daki Evli Çiftlerin Evlilik İlişkilerinin Değerlendirilmesi, Erzurum: Atatürk Üniversitesi Sosyal Bilimler Enstitüsü, Yayımlanmamış Yüksek Lisans Tezi.

Tutarel-Kışlak, Ş. ve Çabukça, F. (2002). 'Empati ve demografik değişkenlerin evlilik uyumu ile ilişkisi', Aile ve Toplum. Eğitim-Kültür ve Araştırma Dergisi, 5, 35-41

Tüik (2018). Evlenme ve Boşan İstatistikleri 2017. Haber Bülteni, 27593 